\title{
FICH252209
}

Queries

Tony Chafer

Dear Author

Please address all the numbered queries on this page which are clearly identified on the proof for your convenience.

Thank you for your cooperation

Q1 Just checking that 'effects' is correctly transcribed and not a mistype for 'affects' 


\section{Education and Political Socialisation of a National-Colonial Political Elite in French West Africa, 1936-47}

Much has been written about the first generation of political leaders of French West Africa, their leadership skills, personal resources and networks. Their attachment to, and close links with, France played a crucial role in determining the pattern of decolonisation in the colony. Through a study of their political socialisation, this article seeks to throw light on the experiences and influences that fashioned their thinking about politics and created a common stock of ideas, norms and values. Focusing in particular on their education at the William Ponty School and two key moments that shaped their political thinking - the Popular Front period (1936-38) and the immediate post-war period (1944-47)—it will be argued that an appreciation of their process of political socialisation enhances our understanding of their political choices. A final section reflects on the legacy of this process in the postcolonial period.

Studies of decolonisation in French West Africa have traditionally drawn attention to a number of factors to explain the reluctance of the colony's political leaders to call for independence. Donal Cruise O'Brien, in a 1965 article, analysed the limits of political choice facing African leaders in the period of decolonisation. The colony's poverty in resources, the lack of educated personnel resulting in dependence on French aid and administrative staff, and gerrymandering by the colonial administration all limited the political choices open to African political leaders. ${ }^{1}$ Michael Crowder added that French West African political leaders' lack of enthusiasm for political independence was hardly surprising, given what had happened in Madagascar, Indochina and Algeria. $^{2}$ But, as Crowder himself acknowledged, it takes more than the economic and political policies of France to explain why this was the case. ${ }^{3}$ Material structures and the political opportunities afforded by the institutional structure were clearly important, but the clinching factor is usually seen as the close links between the colony's political leaders and France: 'Educated at "assimilationist” schools, employed

Correspondence to: Tony Chafer, School of Languages \& Area Studies, Park Building, University of Portsmouth, Portsmouth, PO1 2DZ, UK. Email: tony.chafer@port.ac.uk 
by and large in the French administration, finding their parliamentary feet in the National Assembly of France, devotees of French culture, there was an emotional bond between them and their former masters, which has little parallel in Englishspeaking Africa. ${ }^{4}$ The key role played by these leaders in determining the pattern of decolonisation in French West Africa cannot be doubted. Thanks to their willingness to work with the French government, the transition from colonial rule to political independence was largely smooth and French influence over its former colonial territories was maintained, if not enhanced, as a result of decolonisation.

Yet the facts of having received a French education, speaking French, working for the government and enjoying French culture were no guarantee in themselves of political moderation or loyalty to France. In the inter-war period in France the activities of African nationalist activists and intellectuals such as Lamine Senghor (no relation of the other Senghor-Léopold Sédar-who was later to become the first president of Senegal) and Tiemoko Garan Kouyate are testimony to this. ${ }^{5}$ Similarly, after the Second World War, African students at universities in France were the first group to campaign publicly for independence. ${ }^{6}$ There has been a tendency to assume that the 'Frenchness' of the political leaders of French West Africa-the fact that they spoke French and were deeply imbued with French culture-rendered their pro-French political stance in the run-up to independence in some way 'inevitable'. But this is to reason with the benefit of hindsight: alternative futures, involving a less exclusive relationship with the former colonial power, were imaginable for the former territories of French West Africa-as Sékou Touré (Guinea) and Diawadou Barry (Niger) demonstrated in the 1958 referendum campaign. The fact that independence might be problematic and less immediately attractive did not rule it out as a political option.

So why did most of the first post-war generation of political leaders of French West Africa remain isolated from the spirit of Bandung? Why did they not follow the example of their fellow English-speaking African leaders? Building on the ideas of O'Brien and Crowder, G. Wesley Johnson has suggested that their political choices should be seen as an expression of their 'emotional attachment to the nation state...to the metropole-that is, the French, not African nation.' In contrast, James Genova has suggested that 'there is little indication of an "emotional attachment" to the nation-state [by] the assimilated Africans, especially to the "French" nation." If this is the case, to what were they attached? One response might be to suggest that they were actually critical of the French State, but wedded to the republican ideals of liberty, equality, fraternity and modernity that, in theory at least, provided its ideological underpinning. They were also attached to French language and culture. Yet this was accompanied by a rejection of assimilation and a simultaneous devotion to, and promotion of, African culture: indeed, this represented the very essence of Senghorian négritude and Houphouët-Boigny's defence of 'la personnalité africaine.9 All of this suggests the need for a more carefully nuanced analysis of the political and cultural attachments of this first post-war generation of political leaders of French West Africa. It is with this in mind that the principal aim of this article is to explore further the processes of political socialisation of key actors from this cohort of political leaders in order better to understand the political choices 
they made. In a short final section, some conclusions will then be drawn concerning the legacy of this process of political socialisation in the postcolonial period.

Much has been written about the first generation of political leaders of French West Africa. We know a great deal about the kind of leaders they were, what their leadership skills were and what kinds of personal resources and networks they were able to mobilise to underpin their leadership. ${ }^{10}$ However, their thinking about politics has been little studied. ${ }^{11}$ The importance of normative and ideational structures in shaping the behaviour of social and political actors will be the central focus of this article. ${ }^{12}$ What were the formative experiences and influences that shaped their thinking about politics and that led to the acquisition of shared ideas, norms and values? And how can an understanding of these processes of political socialisation to which they were subject add a further dimension to our understanding of their political choices?

In his edited collection Making Imperial Mentalities, J. A. Mangan usefully defines the process of political socialisation as follows:

Narrowly conceived [it is the] deliberate inculcation of political knowledge, values and practices by agents and agencies formally charged with the responsibility. Broadly conceived, it may be considered to encompass not only political but also apparently non-political learning, formal and informal, calculated and uncalculated, which effects the learning of politically relevant individual and group behaviour. ${ }^{13}$

The key agency formally charged with the inculcation of knowledge is the school system. This has particular significance in the French case as, since the foundation of the école républicaine under the Third Republic, French schools, and primary schools especially, had the vocation not only to transmit knowledge but also to form the new citizens of the Republic. Their aim was explicitly political: to counter the obscurantism of the church schools and the continuing influence of monarchist ideas by establishing a new, republican school system to disseminate the progressive and modernising values of French republicanism. ${ }^{14}$ These embraced defending the principles of 1789 and inculcating notions of patriotism, civic responsibility and respect for order. Outside the schools, political socialisation took place through a variety of formal and informal channels. These included information from official sources such as the colonial government or media and were also the product of an informal, unplanned process of value and norm acquisition through one's social and professional life, through interaction with, for example, friends and colleagues, especially if these were people to whom one looked as models for one's own ideas and behaviour. Significant events that reshaped the political landscape-such as changes of government or political crises-could also influence the acquisition of appropriate political values, norms and practices by political actors.

It is important at this point to bear in mind two potential methodological problems posed by the focus on political socialisation. First, the link between political thinking and behaviour cannot be taken for granted. Many factors, such as political 
opportunity structures, interpersonal rivalries, personal interests, strongly held ideological commitments or ethical beliefs, condition the making of specific political choices in complex ways that cannot be predicted. Second, individuals who have been exposed to similar processes of political socialisation will in practice make political choices that situate them at different points on the left-right political spectrum. The purpose of examining processes of political socialisation is not therefore to seek to explain specific political decisions made at particular conjunctures in some kind of deterministic fashion or to impose an artificial uniformity on a heterogeneous group of individuals who did not at the time see themselves as a coherent group, ${ }^{15}$ but rather to attempt to appreciate the framework of shared ideas, norms, values and implicit rules-what Lynn Hunt calls the 'political culture'-that both informs and shapes the choices made by political actors. ${ }^{16}$ It is the genesis of this shared framework of ideas, which shaped the collective intentions and actions of an elite cohort of French-educated Africans and was forged in a specific colonial context between the 1930s and 1950s in French West Africa, that this article seeks to elucidate.

The political socialisation of this African elite was heavily influenced by the norms and values of French republicanism. While these norms and values do not represent an entirely homogeneous body of ideas, Pierre Rosanvallon has in a recent study set out to define the ways in which they do nonetheless represent a specifically French way of 'doing politics', which he characterises as the 'French political model.' ${ }^{17}$ Rosanvallon's analysis, in which he explores the paradoxes of, and tensions within, this model, can help us to understand the thinking about politics of the elite cohort of Frencheducated African leaders being studied here.

At the level of discourse and institutional structures, Rosanvallon points to the Jacobin, centralising tradition, the tendency to authoritarianism ('la tentation illiberale'), the supreme value of popular sovereignty and the importance attached to the 'educational' role of the state ('l'Etat instituteur') in leading the process of social and political modernisation. He then contrasts this to France's social and political history, which has been marked by popular resistance to centralisation, by often violent political and ideological conflict and by a tendency to social revolution. He identifies the source of this tension between 'two different Frances' as residing in the divorce between representation and reality, in other words the dichotomy between narratives (contained both in official accounts and in those of historians) of the development of the French republican state, on the one hand, and the actual historical experience, the reality of the social history, on the other. ${ }^{18}$ The former is, essentially, an ideal model of French republicanism that emphasises order and unity, while the emphasis of the latter is on struggle. In the specific colonial context within which the political socialisation of this elite cohort of French-educated Africans took place, we shall see that they were exposed to and on occasion adopted elements of the political discourse of both these narratives.

\section{II}

If we now turn to the formal education of this first generation of political leaders of French West Africa, the William Ponty School played a crucial role, as many of 
them graduated from this school during the inter-war period. A few figures give a sense of the school's overwhelming importance in shaping the political destiny of French West Africa in the late colonial period: of the sixteen African deputies elected to the French National Assembly in 1946, eleven were Ponty graduates. ${ }^{19}$ In 1947, twenty-one Ponty graduates were elected to the new territorial assembly in Côte d'Ivoire, twelve in Haute-Volta, five in Niger and nine in Senegal. The equivalent figures for the 1952 territorial assembly elections were fourteen in Côte d'Ivoire, seven in Haute-Volta, two in Niger and sixteen in Senegal. ${ }^{20}$ An impressive number of 'Pontins', as they were called, also became ministers in the first post-independence governments of French West Africa. ${ }^{21}$ Even more tellingly, the first presidents of four of the colony's former territories-Félix Houphouët-Boigny of Côte d'Ivoire, Hubert Maga of Dahomey (present-day Benin), Modibo Keita of Mali and Hamani Diori of Niger-and the first prime minister of independent Senegal, Mamadou Dia, were all graduates of the school: Houphouët-Boigny graduated from Ponty in the mid-1920s, Dia in 1930 and Maga, Keita and Diori in the mid-1930s. ${ }^{22}$

The nature of the education dispensed by Ponty at this time, and the attitudes and values it cultivated, is therefore a useful starting point for understanding the political socialisation of the colony's future political leaders. It will also shed light on the attitudes and values they shared with their contemporaries who passed through the school, many of whom went on to form part of French Africa's wider political elite. As Ruth Schachter-Morgenthau has remarked, 'Most parliamentarians and a high proportion of the leaders of the rival political parties after the war were graduates of Ponty. The temporary political differences of the post-war period, dictated by their party affiliation, often masked their fundamental agreement on major issues. ${ }^{, 23}$ An examination of their education at Ponty will enable us better to appreciate the origins of this 'fundamental agreement'. This section will thus focus, first, on the William Ponty School and then on some key vectors of the wider process of political socialisation to which these future political leaders would have been exposed in the French West Africa of the 1930s.

190 Colonial education in French West Africa had two main functions: to provide a basic education to the African masses and to create a small indigenous elite of colonial auxiliaries loyal to France. ${ }^{24}$ The resources were not available to meet the first objective, so that only some 5 per cent of the population of French West Africa had received any French education by the end of the Second World War. ${ }^{25}$ France was, however, more successful in meeting the second aim, essentially through a small network of upper primary and post-primary schools. The latter were concentrated in the Four Communes of Senegal and the most prestigious of these was the William Ponty School, which was located on Goree until 1938 when it moved to a new site en brousse close to the village of Sébikotane, some 40 kilometres from Dakar. By the end of the Second World War Ponty had produced some 2000 graduates-an average of just over fifty per year-during its forty years' existence, for a total African population in French West Africa of some 15.5 million. It has been described as the Oxford of French West Africa, ${ }^{26}$ although this is somewhat misleading as it was in no sense a university, or even a secondary school providing a general education 
comparable to that provided in a metropolitan lycée. Rather, it provided post-primary vocational education in three sections, training teachers, medical assistants ('docteurs africains') and interpreters and clerks for the colonial service. Moreover, while the school was indeed highly selective, the education provided at Ponty was not even recognised as equivalent to that provided by similar post-primary schools in the metropole. Indeed the diploma it awarded was valid only in Africa, which meant that it was useless as a stepping stone to further study in France. It was not until after the war that Pontins were allowed to study for the baccalauréat, which wasand remains_-the prerequisite for admission to a French university.

210 It is thus misleading to suggest that the education of this elite was 'assimilationist' in its content. ${ }^{27}$ To be sure, French language, with dictation, comprehension and grammar taking pride of place, occupied ten hours per week (approximately a third of the curriculum), with the rest of the curriculum made up of mathematics, physical and natural sciences, geography and history. ${ }^{28}$ But, overall, the curriculum at Ponty 215 until the early 1930s 'was essentially a watered-down version of that in French EPS [upper primary schools] and normal [teacher-training] schools. ${ }^{29}$ Thereafter, following criticism that the school's curriculum had 'become far too abstract and academic', ${ }^{30}$ renewed efforts were made to 'africanise' the curriculum in order to adapt the education provided to what the colonial government perceived as African needs, which meant focusing education more on vocational training and improving agriculture. $^{31}$ This emphasis on 'africanisation' of the curriculum remained the dominant trend until 1945, when African demands for the 'decolonisation' of education, by which was meant an end to 'adapted' education and making metropolitan curricula and diplomas available to Africans throughout French West Africa, initiated an inexorable move towards the introduction of full French metropolitan-style educationincluding the baccalauréat - in French West Africa.. ${ }^{32}$ Thus all the future leaders of French West Africa with whom this article is concerned had passed through Ponty before a real 'assimilationist' education was introduced.

However, if the education provided at Ponty was not assimilationist, in the sense that it did not provide metropolitan-style education with the aim of creating 'Black Frenchmen', as one British commentator at the time suggested, ${ }^{33}$ what was the nature of the political socialisation that took place at Ponty? Clearly, the process did not start at Ponty, but it continued and intensified a process begun in the regional and upper primary schools. It also became more sophisticated and more focused, as Ponty was not simply a school. It was the training ground for the new elite of Franco-African fonctionnaires (civil servants) that the colonial government wanted to create in French West Africa. ${ }^{34}$ What then were the values, assumptions and norms that were inculcated at Ponty and how did Pontins respond to them? The first point is that, despite the limitations of their education, Ponty students neverthe240 less saw themselves as an elite. They remained fiercely proud of the fact that they had graduated from the grande école of French West Africa and of their status as ex-Pontins. ${ }^{35}$ The hurdles they had crossed in order reach the apex of the colony's education pyramid, notably the highly selective school system in which any pupils considered unsuitable for further schooling on either academic grounds or for 
reasons of character had been carefully weeded out, and the highly competitive, federation-wide entry examination to the school were a factor in this. The fact that Ponty was a boarding school, a self-contained community situated on a small island off Dakar, also contributed to this self-perception.

Second, Ponty graduates were imbued with a sense of their modernity. Clearly this is a fluid concept, yet the sense of being 'modern' does encapsulate a key dimension of how members of this French-educated elite defined themselves in relation to 'traditional' African society. One aspect of this is the adoption of a western lifestyle. The importance of the role played by Ponty in this process has been underlined by one of its best-known graduates, Mamadou Dia:

The time at Ponty was very important...it was at Ponty that I really came into contact with western life, with modern life. Before that I did not even know how to wear a jacket, trousers or tie. It was at Ponty that, as part of the school's uniform, I wore a European suit, jacket, tunic and shirt for the first time...I ate at table for the first time at Ponty. . All these things were new to me. ${ }^{36}$

For most Ponty students, their time at the school was also their first real contact with French culture, in particular French literature and history. Dia describes how many of them became avid readers of French literature. ${ }^{37}$ Moreover, French history did not at this time form part of the curriculum in primary or upper primary schools in French West Africa. In these schools they would have studied 'French power, French West Africa and the history of civilisation. ${ }^{38}$ But it was at Ponty that most African students received their first lessons about the history of France ${ }^{39}$ and were encouraged to identify 'with the conquerors of French West Africa rather than with the defeated or colonized Africans' and in their sense of 'loyalty, gratitude and often a strongly felt identification of themselves as French as well as African (despite their realization that they were neither fully equal nor could they fully adopt French culture),. ${ }^{40}$ The strength of this identification with France is strikingly expressed by HouphouëtBoigny in his manifesto for the 1945 Constituent Assembly elections:

My uncle died bravely in the service of France. It is the same uterine blood that runs in my veins. His blood cannot lie. The grand nephew of bloodthirsty black kinglets, I belong to the race of those who, for centuries before the arrival of the French, only knew and subscribed to the law of the survival of the fittest. At school my French teachers taught me man's duty towards his superiors and certain governors and administrators under whom I have had the privilege of serving impressed upon me the deep meaning of this last word. Thus it was France that took me from the bush, from the savage Akoué bush, and launched me on a path that is difficult to follow but whose ultimate objective is EVOLUTION. ${ }^{41}$

However, superior French civilisation did not emerge naturally through some kind of organic process of evolution, but through struggle. Teaching French history to Africans necessarily meant teaching them about the French Revolution and, despite the reservations of some colonial officials that 'ideas of liberty and rebellion might be taken wrongly (i.e. too literally) by young Africans', it seems that the French Revolution enjoyed a place of honour in the curriculum. ${ }^{42}$ At the same time instructions to 
teachers made it clear that it was not the taking of the Bastille and the overthrow of the ancien régime that should be studied. Rather, the struggles of the Revolution should be presented as 'well-intentioned struggles against war itself [and] to promote civilisation. ${ }^{43}$ This chimed with Pontins' sense of representing the forces of modernity, of being at the forefront of France's self-appointed civilising mission in Africa. They identified with the values of republican France and saw themselves as vectors for French republican values in much the same way as French instituteurs were seen as promoters of modernity, in the vanguard of the struggle against obscurantism, in rural France under the Third Republic. ${ }^{44}$

A further key aspect of modernity is that society ceases to be governed by tradition and is organised instead according to abstract principles formulated for that purpose. This meant that, as in metropolitan France, education in French West Africa was secular. ${ }^{45}$ This was seen as essential if education was to succeed in inculcating the rational outlook and 'modern' values associated with French republicanism. In addition, at Ponty particular emphasis was placed on cultivating in students a sense of duty, so as to 'turn youngsters from widely varied ethnic, cultural and religious backgrounds into dedicated functionaries who shared...ideals of service to the French patrie. ${ }^{46}$ The significance attached to the notion of duty is evident in the quotation from Houphouët-Boigny's manifesto above and was considered especially important at Ponty as all Pontins were training to become civil servants.

Thus, although every effort was made to ensure that the education provided at Ponty was not assimilationist, it clearly had an assimilationist dimension. This was a result not only of the exposure to European customs and the emphasis placed on the French language but also of the fact that students were taught to identify with values and with a patrie that were not their own, even if they were not ultimately admitted as full members of that patrie.

Third, and this was no doubt an unintended product of the process of political socialisation that they underwent, Ponty students gained a strong sense of their particular status and strategic importance within the colonial system. Their competence in French and the very fact of having made it to Ponty no doubt encouraged them to see themselves in this way. Moreover, since colonial rule was legitimated in French republican discourse largely by the fact that it was portrayed as civilising, modernising and progressive and since there were so few Europeans in French West Africa, this meant that the small elite of French-educated Africans was in practice destined to play a key role in bringing the French language, culture and values to Africans and acting as a force for 'modernity' in 'traditional' society. ${ }^{47}$ In taking on this role, they were aware that they occupied a key strategic position within the colonial system as intermediaries between 'modern' French and 'traditional' African society.

However, once they took up their appointments in the colonial service, Ponty graduates quickly discovered the practical limits to their elite status. Two surveys of African instituteurs (primary school teachers) (nearly 50 per cent of all Ponty graduates in the period up to 1945 trained as teachers) ${ }^{48}$ provide a remarkable insight into Ponty graduates' perceptions of the dichotomy between their view of themselves as a colonial elite occupying a key strategic position between French and African society 
and their treatment by the colonial administration. Almost all the respondents commented on their poor salaries and working conditions compared to their European counterparts doing the same work. In addition, all respondents in both surveys commented on the lack of respect accorded to them by colonial officials. ${ }^{49}$ Instead, they complained that they were often treated with suspicion as a potentially destabilising influence precisely because of their French education, were subjected to regular inspections and frequently transferred from one post to another for reasons that had nothing to do with their professional competence. The strong sense of selfworth that they had developed while studying at Ponty was not therefore borne out by their experience working for the colonial service.

Despite these grievances, most Ponty graduates_-including most instituteurs — felt a great sense of loyalty to France. ${ }^{50}$ Given what we said above about the treatment of African civil servants working for the colonial service, this strong sense of loyalty to, and identification with, France requires some explanation. One reason was no doubt the relative material benefits that attached to working for the colonial government. Regardless of the discrimination to which they were subject in terms of their salaries and working conditions and whatever the hardships they suffered, their employment in the colonial service enabled them to enjoy a standard of living that was vastly superior to that of the great majority of Africans. Yet this in itself was no guarantee of continuing political loyalty to the colonial power, as the British were to discover in their African colonies after the Second World War. This is where an appreciation of the process of political socialisation of this inter-war cohort of Ponty-educated Africans can help us to understand the nature of this loyalty. To do this we need now to turn to the ideology of French republicanism, to understand how it was represented at Ponty and how Ponty students responded to, reinterpreted and exploited this ideology after leaving the school.

The origins of the French republic lie in the Revolution, which is presented by republicans of all political hues as the victory of modernity over tradition, of reason over obscurantism and of liberty over tyranny. France's civilising mission in Africa was justified by reference to the promotion of these 'universal' values and it was this compelling lesson that African students at Ponty were taught. Yet, given that these values were constantly belied in French West Africa by the inherently authoritarian nature of colonial rule and by their daily experience of colonialism, it would seem paradoxical that French-educated Africans should nonetheless feel such a strong sense of loyalty to France. ${ }^{51}$ One might expect, as Coulibaly has suggested, that they would be obliged 'to make a choice between, on the one hand, "liberty" and the "anticolonial struggle", that give priority to their links with the African people, and on the other, the struggle for colonial domination, that gives priority to solidarity with the colonial power. Because one cannot be at once a resister and a collaborator, anticolonialist and colonialist. ${ }^{52}$ The paradox is, however, more apparent than real, since adherence to French republican values made it possible to believe that they were part of a universal struggle, the ultimate aim of which was the triumph of the values of modernity, reason and liberty over tradition, obscurantism and tyranny. Moreover, their strategically important position at the meeting point between Africa and France, mediating 
between and interpreting each culture for the other, placed them at the nodal point of the new Franco-African society that senior colonial officials and many of the Frencheducated African elite shared as their vision for the future. ${ }^{53}$ As a result, Ponty students in the inter-war period did not see any necessary contradiction between their criticism of colonial rule and their identification with, and political loyalty to, French republicanism. Lacking at this point any actual direct experience of France itself, their loyalty was to an ideal vision of a republican France that was presented as modernising, progressive and generous.

Thus Ponty graduates and senior colonial officials shared certain assumptions and values, notably the commitment to French republicanism and the vision of a future Franco-African society derived from the best elements of French and African culture. However shared assumptions and values do not mean political agreement. The points of contention that were emerging in the 1930s were: who would define and interpret the values and norms of French republicanism for African needs and who would control politically this new Franco-African society? The coming to power of the Popular Front in 1936, at the very moment when key political actors were beginning to stake out their positions, was an important moment in both defining the terms of this emerging struggle for political influence and laying the foundations for future political alliances.

\section{III}

The Popular Front came to power promising wide-ranging, albeit ill-defined, colonial reform. Its election victory in 1936 raised the political hopes of the French-educated African elite in French West Africa and was received particularly enthusiastically in the coastal areas and the main towns. In Dakar, for example, on 14 July 1936 there was a colourful 5,000-strong procession through the streets, led by some forty Europeans, with red flags, clenched fists and 'Popular Front' logos stuck onto colonial helmets! ${ }^{54}$ The impact of the Popular Front was not, however, confined to these areas. African teachers, often encouraged by their French colleagues, carried the Popular Front message into the interior of French West Africa. Popular Front committees sprang up in towns throughout the colony and raised African hopes for substantive change. ${ }^{55}$ Later in the year Marius Moutet, the first ever Socialist colonial minister, became the first colonial minister to visit French West Africa. As a clear sign of his government's reformist intentions, he used his visit personally to install the new governor-general, Marcel de Coppet, whom he appointed to replace Jules Brévié. He gave a speech on arrival in the colony in which he promised to continue France's 'mission fraternelle' in Africa by improving the human rights of colonial peoples living under French republican rule and which ended by proclaiming that: 'The Republic is the country of the liberation of men, whoever they are. ${ }^{56}$ This 'universalist' language reflected the Socialist (SFIO) view of the French republican imperial project as leading ultimately to the liberation of all those living under French rule.

The Popular Front thus represented a crucial moment in the political socialisation of the inter-war generation of French-educated Africans as it encouraged them to 
make a distinction between the 'colonial Frenchman' who was their traditional interlocutor in French West Africa and whose racism and authoritarianism were a feature of 'right-wing colonialism', and the 'true republicans' of the left who presented themselves as progressive and generous colonial modernisers. ${ }^{57}$ Whereas the former laid emphasis on order and stability, the latter appealed to the populist and progressive tradition in French republicanism. This humanitarian colonialism of the Popular Front needs to be understood in the context of the prevailing ethos of the left and centre-left at this time, which projected its colonisation altruiste (colonial humanism) as promoting closer international links and greater co-operation between the peoples of the world and according to which the colonial power took on the responsibility to improve the material and moral conditions in which the less advanced, subject peoples lived. ${ }^{58}$ Within French West Africa it was through their contact with French teachers, the majority of whom were left-wing and committed to promoting the universal and progressive values of French republicanism, that most French-educated Africans came into direct contact with such political ideas. ${ }^{59}$ These contacts, by their own admission, had a significant formative influence on their own political ideas since they appeared to open the door to a reformed, non-racial Greater France. ${ }^{60}$ And in the struggle to achieve this dream of a new society, Moutet's message was that their natural allies were not other Africans but French progressive republicans-colonial reformers with whom they could collaborate in an effort to realise their common dream of an alternative Greater France conceived as a non-racial, supra-national federation.

It is important to understand the political context within which the inter-war French-educated elite espoused this assimilationist vision. As subjects they did not enjoy the political rights and freedoms enjoyed by African citizens resident in the Four Communes. It is not therefore surprising that their political campaigns should focus on gaining these rights. In allying themselves with left republicans they adopted the universalist discourse of the Popular Front to stake their claim to equal rights with French citizens. In this sense their adoption of assimilationist themes should be seen as 'situational': it does not mean that they accepted the rejection, 430 indeed destruction, of African cultures implicit therein nor does it mean that they accepted without reservation the political terms on which this assimilationist vision was put forward. Rather, they wanted, and expected, to negotiate as equal partners the political structures that would govern the Franco-African society that both the new left republican government and the inter-war elite of French-educated Africans envisioned.

The outbreak of war and the subsequent imposition of the Vichy regime in 1940 brought a return to a 'harder', more authoritarian style of colonial rule in French West Africa, under which all Africans were subjects and it was no longer possible, as it had been in the past, for 'deserving' French-educated Africans to become French citizens. As a result racial discrimination between whites and blacks in French West Africa became more stark. Yet, in a somewhat perverse way, the open racism of the Vichy regime actually helped republicans, insofar as it made it possible for them to portray the Vichy period as an aberration by contrasting Vichy colonial policy with their own approach, which accorded political rights to Africans. ${ }^{61}$ They 
could thus re-create the notion after the war that French colonialism, republican-style, was progressive and modernising, and suggest that it was through integration into the Republic, rather than separation from it, that African emancipation would be achieved.

This notion was clearly articulated for the first time by the Popular Front government and it was adopted by the inter-war French-educated elite as a basis for their claim to equal rights. De Coppet was recalled to Paris in 1938 and the Popular Front government fell without having the time to deliver on its reformist plans. Some historians have justifiably argued that the Popular Front would never have been able to deliver its reform plans within a colonial context, caught as it was in the innate contradictions between its liberal reformism and the inherently authoritarian nature of colonial rule. ${ }^{62}$ However, the key point here is that, after the war, those Africans who had looked to the Popular Front government as opening the possibility for a renegotiation of the political compact between the colonial government and the French-educated elite now looked to the return of a republican regime, dominated by the left and with Moutet reinstalled as colonial minister, to deliver on its commitment to a non-racial Greater France. Their expectation of real change was also heightened by the changed balance of political forces; France emerged from the war weakened and also indebted to Africans for their support during the war. General De Gaulle's speech opening the Brazzaville conference in 1944 marked a recognition that the old colonial regime had come to an end and that colonial reform was now inevitable. ${ }^{63}$ Political liberties, including freedom of association and the right to form political parties and trade unions, partially granted under the Popular Front, were now to be extended to the whole of French West Africa, and the principle of African elected representation in the future National Assembly in Paris was accepted.

As soon as the war ended there was an upsurge in political and trade union activity, the main focus of which was an end to racial discrimination and a claim for 'equal pay for equal work' with Europeans. The decision to rename the colonial empire the French Union in 1946 and the affirmation in the new constitution of the Fourth Republic that metropolitan France and its overseas possessions formed a 'one and indivisible republic' seemed to suggest that Paris was prepared to respond positively to such demands. ${ }^{64}$ These campaigns set the parameters of the political campaigns of the French-educated elite in French West Africa after the war: the demand for decolonisation within the context of continued links with France. ${ }^{65}$

To be sure, this assimilationist vision of a Greater France with equal rights for all involved a political sleight of hand, since all Africans would in practice never be able to achieve equal rights through integration into a 'one and indivisible France', if for no other reason than that there was no realistic prospect of the metropole funding it. French-educated African leaders were not necessarily dupes in this, but in the post-war context they knew that 'it was much harder to reject a call for equality based on French republican ideals than to fight against a nationalist call for independence. ${ }^{66}$ Nor were they prepared to accept the elimination of their own culture implicit in the notion of cultural assimilation. ${ }^{67}$ The vision nevertheless provided a powerful incentive for an elite cohort of French-educated Africans who came to 
political maturity between the wars to espouse the notion that progress, modernisation and liberty would come through the maintenance of a relationship with France, the terms of which they would play the key role in negotiating. An understanding of this is essential to an appreciation of their political stance after the war.

\section{IV}

The cohort of French-educated Africans on whom we are focusing here was educated at Ponty between the wars and became active in politics when the Vichy regime ended in French West Africa in 1943. This was also the moment when the French Communist Party, which was in government from the liberation of France until 1947, decided to take a hitherto unprecedented interest in Africa. Communist activists set up associations (Groupes d'actions républicaines, France combattante) in Africa. These groups had an almost exclusively European membership until 1946, when the Communist Party re-established a colonial section under Raymond Barbé and encouraged its activists to create Groupes d'Etudes Communistes (Communist study groups) in the colonies. Their objective was to co-ordinate the activities of these various groupings, to attract African members and, finally, 'the creation in each territory of a democratic (or progressive) party with the aim of uniting Africans (together with a few French people) around the programme of the CNR [Conseil National de la Résistance].68

The Communist Party's official line was that, given its economic under-development and the lack of a proletariat, French West Africa was not yet ready for the establishment of Communist Party sections. ${ }^{69}$ Rather, African activists should be encouraged to join with French Communists and the metropolitan working class in the common struggle against the forces of capitalism in the form of metropolitan and colonial trusts. Thus, Groupes d'Etudes Communistes were formed in the main urban centres of French West Africa to provide political education and a meetingplace for all those, French and Africans, who shared this aim. In ideological terms, the training provided by the Groupes d'Etudes Communistes was Marxist-Leninist in inspiration; they promoted a radical anti-imperialist line, but, the Communist Party having firmly established itself during the Occupation as a French national party, it did not support-or at best was ambivalent about-colonial nationalist movements. Rather, having played a central role in the re-branding of the empire as the French Union, its political stance was to campaign for a united struggle of all the peoples of the French Union against Anglo-American imperialism. In Senegal, for example, it organised a meeting of the France-USSR association in 1945. It also encouraged its activists to take posts as teachers, engineers and technicians, where they often formed close and enduring friendships with French-educated Africans. ${ }^{70}$ In the context of French politics, the stance of the Communist Party should be seen as rooted in the traditions and ideas of French left republicanism dating back to the Revolution of 1789 and that first found political expression in French West Africa during the Popular Front. ${ }^{71}$ 
It is remarkable how many of the future political leaders of French West Africa, and their close collaborators, were active in the Groupes d'Etudes Communistes. For example, we know that Houphouët-Boigny attended meetings of both the Abidjan and Dakar Groupes, that Ouezzin Coulibaly was a member of the executive committee of the Bobo-Dioulasso Groupe and that Modibo Keita's brother, but not Modibo Keita himself, was a member of the Bamako Groupe. We also know that Hamani Diori's close collaborator and second-in-command in the Parti Progressiste Nigérien, Boubou Hama, who was to become president of Niger's National Assembly after independence, was a member of the Niamey Groupe, and that the country's future interior minister, Djamballa Yansambou, was its president. ${ }^{72}$ Even those French-educated Africans who did not play an active part in these various groupings came into contact with Communist ideas through the propaganda activities of these and other groups and through an increasingly active local press. ${ }^{73}$

Through the Communist Party, such ideas also had a significant influence on the political programme of French West Africa's first trans-territorial party, the Rassemblement Démocratique Africain (RDA), which was launched with Communist support at a founding congress in Bamako in October 1946. Although the party became associated with radical politics because of its links with the Communist Party, it was not a nationalist party in the sense that it emphatically did not support secession from France. Its launch manifesto stated:

Our adhesion to the French Union, that we solemnly proclaim, is justified by a realistic view of the world's political problems, by our confidence in Africa's destiny and by the certainty that, despite the forces of reaction, we shall win the liberal democratic and human conditions which will make it possible for Africa freely to develop its particular talents and skills.

For this reason, tens of thousands of Africans, fraternally united with French people who share this democratic ideal, have joined together in parties, movements or democratic, progressive or popular unions. ${ }^{74}$

The propagation of such ideas throughout French West Africa played a key role in reinforcing the identification of French-educated Africans with the modernising norms and values of French left republicanism. However, whereas it was with the Socialists, and in particular the Socialist colonial minister Marius Moutet and his appointee as governor-general, Marcel de Coppet, that the French-educated elite sought to work to implement reforms in 1936-38, in 1946 Moutet was seen as an obstacle to further progress. He did everything in his power to prevent the founding congress taking place and put pressure on African Socialist députés (Léopold Senghor, Lamine Guèye, Yacine Diallo) not to attend, thereby increasing the Communist Party's influence over the congress's proceedings and enhancing its credentials as the only truly anti-imperialist party in France. To French-educated Africans it was thus the Communist rather than the Socialist Party that now represented the political alternative to old-style right-wing exploitative colonialism on the one hand and secession from France on the other. Moreover, the Groupes d'Etudes Communistes did not cease to exist with the creation of the Rassemblement Démocratique Africain; rather than intervening directly in the political life of the territories, they now took 
on the role of study circles and the provision of training for political activists. As SuretCanale reflects, the Communist Party's methods of organisation and action thus continued to exert a profound influence on the future political leaders of French West Africa. $^{75}$

After the war the Comités d'Etudes Franco-Africaines (CEFA), the first of which was created in Dakar in February 1945, were also an important vector for the spread of left republican ideas in the territory. The Comités supported a policy of colonial modernisation through closer integration with the republic: 'The CEFAs wish to see this French community come into being under the emblem of the Republic: LibertyEquality-Fraternity. ${ }^{, 76}$ The point was underlined in a letter from the Dakar section of the Comités d'Etudes Franco-Africaines to Senghor: 'We are neither separatists nor conspirators. We simply want to gain the right to be members of the French family as equals and not as poor relations.' The same letter also proclaimed their intention of working within 'republican legality' for 'the progressive emancipation of Africans' and for 'French nationality... which we demand as a matter of urgency. ${ }^{\text {'7 }}$ Lamine Guèye was appointed its political director. Left republican ideas also spread through the local press, notably the newspaper Réveil, through the Universite Populaire Africaine, which was run by French teachers who organised evening classes as well as public lectures on contemporary political and social issues, and through contacts between the local Groupes d'Etudes Communistes and the Dakar trade union federation that was affiliated to the Communist Confédération Générale du Travail. ${ }^{78}$

\section{V}

The norms and values to which the inter-war generation of French-educated Africans felt a sense of loyalty were the product of a specific process of political socialisation that can be understood only through an appreciation of, on the one hand, the particular nature of the French education that they received and the context in which they received it and, on the other, the formative political experiences from which they acquired their political values and attitudes. These processes of political socialisation have left a triple legacy in francophone West Africa. First, they led to the emergence of a dependent 'national-colonial' elite that occupied a crucial strategic position at the intersection of French and African society. This elite was dependent, not in the classic neocolonial sense that it had no autonomous power, but rather in the sense that its position of power depended on its strategic position at the political interface between French and African society. This actually meant that it occupied a position of considerable power and it is this, rather than its loyalty to the French nation-state, that explains its attachment to the maintenance of close links with France.

Second, with regard to the identification with French left republicanism, this became associated in the minds of this generation of French-educated Africans with modernisation and progressive politics. The corollary of this was a distrust of 'Anglo-Saxon' liberal politics, portrayed as the harbinger of capitalism which was the root cause of the economic exploitation of the colonies. ${ }^{79}$ Moreover, British colonial policy in Africa was seen as having promoted indirect rule, the effect of which was 
to bolster the power of the traditional chiefs and limit that of the educated elite. For this reason, British policy was portrayed in French West Africa as reactionary because it maintained the particularism of African societies and retarded the economic, social and political development of Africa by favouring traditional elites over modernising western-educated elites. French policy, in contrast, was seen as superior because it was carried out in the name of the universal republican values of liberty, equality and fraternity. One important consequence of this was that there was for many years an enduring distrust of American and British intentions in Africa among French-educated African leaders of this generation, which manifested itself as a reluctance to undertake any rapprochement with anglophone African leaders who were perceived as too close to the United States or Britain.

The final dimension of the political legacy of the processes of political socialisation examined here can be discerned at the level of the thinking about politics of this interwar generation of French-educated African leaders, which was heavily influenced by a set of norms and values derived from French republicanism. This is reflected, first, in a belief in the centralisation of power, the unitary structure of the state and in government claims to represent and express the will of 'the people' over and above the sectional claims of particular interest groups, clans or ethnic groups. Taken together, these have led to a tendency towards intolerance of political opposition and more broadly to a deep distrust of 'Anglo-Saxon' liberalism and pluralist politics. The progressive and modernising values of French republicanism, and this includes left republicanism, have not therefore necessarily been associated with a belief in the values and norms of liberal democracy. Moreover, we have seen that, at the end of the Second World War, the Communist Party incarnated the ideas and values of French left republicanism. In terms of political organisation, its guiding principles were the twin notions of the vanguard party and democratic centralism. Second, the notion of the state as a civilising force, educating and promoting modernisation in the face of a backward-looking, traditionalist civil society is also an integral element of this republican narrative. In this view, and in the absence of progressive and modernising elements within civil society, the responsibility for promoting the liberty of citizens must be assumed by the State. The influence of these ideas was further reinforced by the fact that all these African leaders belonged to a language community that locked them into a francophone world.

The legacy of this way of thinking about politics can be seen in postcolonial French West Africa in the preference for single-party rule, the hostility to autonomous groups and the notion of the State, controlled by the party, at the forefront of the struggle for progress and modernisation. These were common themes in the political thinking and discourse of both the political left and right and their legacy can be seen as strongly in the political line and treatment of political opposition by Keita's left-wing Union Soudanaise (US-RDA) as in Houphouët-Boigny's conservative Parti Démocratique de la Côte d'Ivoire (PDCI-RDA), which ruled Côte d'Ivoire as the single party from 1960 to 1990. As Jean-Pierre Dozon has commented, 'the PDCI was for 30 years the single party in Côte d'Ivoire and, despite its right-wing politics, it functioned using methods that were exactly the same as those used by the PCF in its political 
youth. ${ }^{80}$ This is not of course to suggest that the preference for authoritarian, singleparty rule was unique to postcolonial Francophone Africa. All African leaders inherited colonial states that were ill-prepared for independence: poor in resources and qualified personnel, often riven by submerged-or not so submerged-ethnic rivalries, they had no tradition of democratic processes and institutions and were economically under-developed. The pressures towards authoritarian rule were, in the immediate postcolonial era, virtually irresistible. What was distinctive in Francophone Africa was the way in which the move to authoritarianism was underpinned by an explicit discourse of modernisation rooted in the traditions of French left republicanism. ${ }^{81}$

\section{Acknowledgements}

The author wishes to thank Emmanuel Godin and Sue Wright for helpful comments on an earlier draft of this article.

\section{Notes}

[1] Cruise O'Brien, 'The Limits of Political Choice in French West Africa: 1956-1960'.

[2] Crowder, 'Independence as a Goal in French West African Politics: 1944-60', 40.

[3] Ibid.

[4] Ajayi and Crowder, eds, History of West Africa, vol. 2, 772. See also Crowder, 'Independence as a Goal', 40-41.

[5] For a study of these early nationalists, see Wilder, The French Imperial Nation-State, 179-85; see also Spiegler, 'Aspects of Nationalist Thought'; Dewitte, Les Mouvements Nègres en France.

[6] See Chafer, 'Students and Nationalism' for an analysis of the role of the student movement in the decolonisation of French West Africa. In The End of Empire in French West Africa I argue that the activities of this radical nationalist movement played a significant role in determining the pace, if not the fact, of decolonisation in the colony.

[7] Wesley Johnson, 'The Triumph of Nationalism in French West Africa', 313, emphasis in original.

[8] Genova, Colonial Ambivalence, 256.

[9] Benoist, L'Afrique Occidentale Française, 69.

[10] See, for example, Cruise O'Brien, Saints and Politicians; Dia, Mémoires; Baulin, La Politique intérieure and La Politique africaine; Guèye, Sur les sentiers du temple; Siriex, Félix Houphouët-Boigny; Zan, Ouezzin Coulibaly; Vaillant, French and African.

[11] Schachter-Morgenthau, Le Multipartisme en Afrique de l'ouest francophone, 13-14, 21-24, acknowledges the importance of the William Ponty School, as does Le Vine, in his Political Leadership in Africa, when he mentions the 'seminal role of the Ecole Normale William Ponty in schooling what was virtually an entire generation of African leaders', p. 5, but he does not investigate how their education at Ponty impacted on their thinking about politics.

[12] See for example Crawford, Argument and Change in World Politics.

[13] Mangan, Making Imperial Mentalities, 1-2.

[14] Price, A Concise History of France, 197-98.

[15] In this context Jean-Hervé Jézéquel usefully warns us that Ponty graduates formed 'an educated elite that was on the contrary extremely heterogeneous and constantly subject to a whole range of centrifugal forces'. 'Les enseignants comme élite politique', 519-20. 
[16] Hunt, in her Politics, Culture and Class in the French Revolution, 10, defines 'political culture' as 'The values, expectations, and implicit rules that expressed and shaped collective intentions and actions'.

[17] Rosanvallon, Le Modèle politique français.

[18] Ibid., 11.

[19] Sabatier, 'Educating a Colonial Elite', 209.

[20] Benoist, La Balkanisation, 77.

[21] 'Une pépinière d'hommes politiques: L'Ecole William-Ponty', 23.

[22] All of these five were elected to the French National Assembly after the war: Félix HouphouëtBoigny and Hamani Diori in 1946, Hubert Maga in 1951 and Modibo Keita and Mamadou Dia in 1956. One of the other territories, Haute-Volta, was led by a Ponty graduate, Ouezzin Coulibaly, who was a close collaborator of Houphouët-Boigny and a leading figure in the Rassemblement Démocratique Africain. He was elected to Paris in 1946 and again in 1956 and served as the Vice-President of its Government Council until 1958. But for his premature death he would almost certainly have become the first president of independent Haute-Volta (present-day Burkina Faso). Of the remaining two original territories of French West Africa, Guinée chose immediate independence in 1958 under Sékou Touré's leadership. As he was not a Ponty student, his political choices and career do not concern us here. Moktar ould Daddah, the first president of independent Mauritania, was also not a Ponty student, although he studied in France from 1948 to 1956, where he graduated in law.

[23] Schachter-Morgenthau, Le Multipartisme en Afrique de l'ouest francophone, 21.

[24] Bouche, 'L'Enseignement dans les territoires français'; Chafer, 'France's "mission civilisatrice" in Africa', 148-58.

700 [25] Chafer, 'Decolonisation and the Politics of Education', 375.

[26] Schachter-Morgenthau, Le Multipartisme en Afrique de l'ouest francophone, 13.

[27] Government spokesmen regularly claimed that French colonial education was assimilationist, insofar as it aimed at creating 'a true Frenchman in language, in his soul, in his calling'. Speech by $\mathrm{H}$. Gautier, private secretary to the Minister of Education, reproduced in L'adaptation de l'enseignement aux colonies, 293. However, for a systematic refutation of the notion that French education in West Africa before the end of the Second World War was assimilationist, see Bouche, 'Autrefois, notre pays s'appelait la Gaule', 110-22.

[28] Sabatier, "Elite" Education in French West Africa, 260-61.

[29] Sabatier, 'Educating a Colonial Elite', 126.

[30] Davesne, 'Rapport sur l'AOF de l'adaptation de l'enseignement', 93.

[31] Bouche, 'L'école rurale en Afrique Occidentale Française'.

[32] Chafer, The End of Empire in French West Africa, 94-98.

[33] Mumford, Africans Learn to be French.

[34] Sabatier, 'Educating a Colonial Elite', 110, 127-28.

[35] Sabatier, "Elite" Education in French West Africa', 265.

[36] Dia, Mémoires, 20.

[37] Ibid., 22.

[38] Bouche, 'Autrefois, notre pays s'appelait la Gaule', 117.

[39] Dia, Mémoires, 29.

[40] Sabatier, 'Educating a Colonial Elite', 83. Sabatier points out that this identification of Pontins with the conquerors of French West Africa was actually accurate insofar as African soldiers provided most of the manpower to 'pacify' French West Africa.

[41] Bernard Dadié, Carnets de prison, 262, cited in Coulibaly, 'Elites "évoluées" et populations "indigènes" en Côte d'Ivoire', 326. The capitalisation is in the original. It should be noted that the great uncle with whom he identifies was killed by the Akoué because he was suspected of collaborating with the French.

[42] Sabatier, 'Educating a Colonial Elite', 82-83. 
[43] 'Circulaire sur la réorganisation de l'enseignement', Journal Officiel de l'AOF, supplement, 10 May 1924, 339.

[44] The notion of the African instituteur as a 'model' is a recurrent theme in the responses to the 1944 survey (see n. 48 below). For a description of how French teachers were viewed in Third Republic France, see Wright, France in Modern Times, 247.

[45] Conklin, A Mission to Civilize, 83.

[46] Sabatier, 'Educating a Colonial Elite', 109.

[47] Conklin, A Mission to Civilize, 81-86. By 1939 the majority of European teachers in French West Africa were no longer teaching and instead had taken on a largely supervisory function vis-à-vis their African colleagues; see Sabatier, 'Educating a Colonial Elite', 283; 'Annual report on school year 1938-39', AAOF (Archives de l'Afrique Occidentale Française) [Dakar] 2G39/92, 6.

[48] Sabatier, “Elite” Education in French West Africa', 252. Moreover, of the five future political leaders mentioned above, Diori, Maga, Keita and Dia all graduated from Ponty's teaching section. Houphouët-Boigny in contrast trained as a medical assistant.

[49] The first survey was organised by the then Director of Ponty, Charles Béart, who received responses from fifty-one ex-Ponty instituteurs. The second was a much larger survey, to which 517 instituteurs and 378 pupils (from Ponty and the Frédéric Assomption School in Bamako) replied. The returns from both surveys are available in the Archives: AAOF 075/31 for the 1938 survey and $0345 / 31$ for responses to 1944 survey. The tables collating the results of the latter are not however available in the Archives and were kindly provided to me by Roger Dumargue from his personal archives. I have reproduced these in Chafer, 'Decolonisation and the Politics of Education', 413-24, in order to make them more widely available.

[50] Sabatier, "Elite” Education in French West Africa', 265-66.

[51] See also Cutter, 'The Genesis of a Nationalist Elite', 118-19, for a discussion of the treatment by the colonial administration of members of the French-educated elite which suggests that their elite status was in practice often perceived ambivalently by French officials.

[52] Coulibaly, 'Elites “évoluées" et populations "indigènes" en Côte d'Ivoire', 347.

[53] See, for example, Governor-General Brévié's comments about bringing into being a new 'Franco-African culture' in his opening address to the Government Council of French West Africa on 24 December 1932, reported in the Bulletin de l'Enseignement de l'AOF, 80, JulyDecember 1932, 171. As Gary Wilder has pointed out, this vision of a new Franco-African culture was shared by African intellectuals in the négritude movement at this time; see Wilder, The French Imperial Nation-State, esp. 5-9, 43-117, 232-55.

[54] Bernard-Duquenet, Le Sénégal et le Front Populaire, 65-66; Person, 'Le Front populaire au Sénégal', 88.

[55] Cutter, 'The Genesis of a Nationalist Elite', 120-8.

[56] Paris-Dakar, 28 Sept. 1936, 3, 5.

[57] Chafer and Sackur, eds, French Colonial Empire and the Popular Front, 16-17.

[58] The Radical former colonial minister Albert Sarraut had expressed this view in his Grandeur et servitude coloniales, 106. Cf. also Girardet, L'Idée coloniale en France, 193-95. As Martin Thomas rightly points out, the notion of colonisation altruiste is somewhat misleading, since 'Popular Front reformers never challenged a racially ordered colonial system, believing that the white man's burden derived from the innate superiority of republican cultural values' The French Empire between the Wars, 277.

[59] Cutter, 'The Genesis of a Nationalist Elite', 121.

[60] Person, 'Le Front populaire au Sénégal', 100. This was also confirmed in a personal communication to the author by Amadou Ndene Ndaw, Dakar, 31 March 1990.

[61] Ginio, French Colonialism Unmasked, 115, 173-79.

[62] Thomas, The French Empire between the Wars, 277.

[63] Speech quoted in full in Gbagbo, Réflexions sur la conférence de Brazzaville, 66-69. 
[64] The Constitution of the Fourth Republic stated that: 'France forms with its overseas peoples a Union founded on equality of rights and duties, without distinction of race or religion'.

[65] Chafer, The End of Empire in French West Africa, 93-94, 99.

[66] Ginio, French Colonialism Unmasked, 178.

[67] Cf. Person, 'Le Front populaire au Sénégal', 82, 86-87; speech by Senghor on 10 Sept. 1937 to the Dakar Chamber of Commerce, reproduced in Liberté 1, 19-20; Wilder, The French Imperial Nation-State, 201-55.

[68] Suret-Canale, Les Groupes d'Etudes Communistes, 24.

[69] Ibid., 24-25.

[70] Dozon, Frères et sujets, 330. J. Suret-Canale also refers to Communist activists who created a Communist study group at Ponty in the 1930s, describes the friendships that developed between Communists and French-educated Africans in French West Africa and publishes photos of those involved in his Les Groupes d'Etudes Communistes, 39, 44, 183-84.

[71] Since the Popular Front period the Communist Party had repositioned itself as a French national party that 'assiduously cultivated patriotism, casting the workers as the heirs of 1789 and the true guardians of the republic'. Evans and Godin, France 1815-2003, 101.

[72] Suret-Canale, Les Groupes d'Etudes Communistes, 54-68.

[73] Newspapers such as Le Réveil and its supplement Dakar-Jeunes in Senegal and L'Observateur du Soudan adopted a broadly left republican stance. Widely read by French-educated Africans, they were harshly critical of the colonial regime. Such ideas also circulated through the activities of the Comités d'Etudes Franco-Africaines (CEFA), which sprung up in many urban centres of French West Africa after the war; see Chafer, The End of Empire in French West Africa, 70-72. See also below.

780 [74] Dalloz, Textes sur la décolonisation, 35-36.

[75] Suret-Canale, Les Groupes d'Etudes Communistes, 69.

[76] Undated circular sent out to all CEFA sections, AAOF 17G526/144.

[77] Letter from CEFA, Dakar, to Senghor, 25 Feb. 1944, AAOF 17G127/17.

[78] Réveil was originally produced by the France combattante group. It was edited by Charles-Guy Etcheverry, a Socialist local councillor who joined the Rassemblement Démocratique Africain in 1948 and effectively made the newspaper the mouthpiece of the Rassemblement Démocratique Africain. As for the Confédération Générale du Travail (CGT), it was important in terms of promoting radical anti-imperialist ideas in French West Africa and simultaneously cementing a network of enduring links between French and African trade unionists. There is insufficient space to discuss this dimension here. However it has been thoroughly covered in Delanoue, 'La CGT et les syndicats de l'Afrique noire de colonisation française' and Dewitte, 'La CGT et les syndicats d'Afrique occidentale française'.

[79] In this context, it should be noted that the term 'liberal' in the Rassemblement Démocratique Africain manifesto quoted above should not be interpreted in an Anglo-Saxon sense as referring either to free markets or pluralist politics; 'liberal' here is used in the French sense to refer to the liberty that is the product of social and economic development and modernisation.

795 [80] Dozon, Frères et sujets, 335.

[81] For a fuller discussion of the influence of French political culture on Francophone Africa, see LeVine, Politics in Francophone Africa, esp. 96- 103.

\section{References}

Ajayi, A. and M. Crowder, eds. History of West Africa, Vol. 2. 2nd edn. Harlow: Longman, 1987.

Baulin, J. La Politique africaine de Houphouët-Boigny. Paris: Eds Eurafor-Press, 1980.

—. La Politique intérieure de Houphouët-Boigny. Paris: Eds Eurafor-Press, 1982.

Benoist, J.-R. de. La Balkanisation de l'Afrique Occidentale Française. Dakar: Nouvelles Editions Africaines, 1979. 
—. L'Afrique Occidentale Française de 1944 à 1960. Dakar: Nouvelles Editions Africaines, 1982. Bernard-Duquenet, N. Le Sénégal et le Front Populaire. Paris: L'Harmattan, 1985.

Bouche, D. 'Autrefois, notre pays s'appelait la Gaule....Remarques sur l'adaptation de l'enseignement au Sénégal de 1817 à 1960'. Cahiers d'études africaines, 29 (1968): 110-22.

_ _. 'L'Enseignement dans les territoires français de l'Afrique Occidentale Française de 1817 à 1920: Mission civilisatrice ou formation d'une élite?' 2 vols. Lille: Atelier Reproduction des Thèses, University of Lille-III, 1975.

—_. 'L'école rurale en Afrique Occidentale Française'. In Etudes africaines offertes à Henri Brunschwig. Paris: Publications de l'Ecole des Hautes Etudes en Sciences Sociales, 1982, 271-96.

Chafer, T. 'France's "mission civilisatrice" in Africa: French Culture not for Export?'. In Popular Culture and Mass Communication in Twentieth Century France, edited by R. Chapman and N. Hewitt. Lampeter: Edwin Mellen Press, 1992.

- . 'Decolonisation and the Politics of Education in French West Africa, 1944-58'. Unpublished $\mathrm{PhD}$ thesis, University of London, 1993.

- 'Students and Nationalism: The Role of Students in the Nationalist Movement in Afrique Occidentale Française'. In AOF: réalités et héritages: Sociétés ouest-africaines et ordre colonial, 1895-1960, edited by C. Becker, S. Mbaye and I. Thioub, Vol. 1. Dakar: Direction des Archives du Sénégal, 1997, 388-407. The End of Empire in French West Africa. Oxford: Berg, 2002.

Chafer, T. and A. Sackur, eds. French Colonial Empire and the Popular Front. Basingstoke: Macmillan, 1999.

Conklin, A. A Mission to Civilize. Stanford, CA: Stanford University Press, 1997.

Coulibaly, T. "Elites "évoluées" et populations "indigènes" en Côte d'Ivoire pendant la colonisation (1946-60): Les valeurs paradoxales d'une mobilisation politique'. Unpublished doctoral thesis, University Paris I, 1997.

Crawford, N. Argument and Change in World Politics: Ethics, Decolonization and Humanitarian Intervention. Cambridge: Cambridge University Press, 2002.

Crowder, M. 'Independence as a Goal in French West African Politics'. In French-speaking Africa: The Search for Identity, edited by W. H. Lewis. New York: Walker, 1965, 15-41.

Cruise O'Brien, D. 'The Limits of Political Choice in French West Africa: 1956-1960'. Civilisations 15, no. 2 (1965): 206-26.

- Saints and Politicians. Cambridge: Cambridge University Press, 1975.

Cutter, C. H. 'The Genesis of a Nationalist Elite: The Role of the Popular Front in the French Soudan (1936-1939)'. In Double Impact: France and Africa in the Age of Imperialism, edited by G. W. Johnson. Westport, CT: Greenwood Press, 1985, 107-39.

Dalloz, J. Textes sur la décolonisation. Paris: Presses Universitaires de France, 1989.

Davesne, A. 'Rapport sur l'AOF de l'adaptation de l'enseignement dans les colonies'. In L'adaptation de l'enseignement aux colonies: Rapports et compte rendu du Congrès intercolonial de l'enseignement dans les colonies et dans les pays d'outre-mer, 25-27 septembre 1931, prepared for the Exposition Coloniale Internationale 1931. Paris: H. Didier, 1931, 85-106.

Delanoue, P. 'La CGT et les syndicats de l'Afrique noire de colonisation française, de la Deuxième Guerre Mondiale aux indépendances'. Mouvement Social 122 (1983): 103-16.

Dewitte, P. 'La CGT et les syndicats d'Afrique occidentale française'. Mouvement Social 117 (1981): $3-32$.

- Les Mouvements Nègres en France, 1919-1939. Paris: L’Harmattan, 1985.

Dia, M. Mémoires d’un militant du tiers-monde. Paris: Publisud, 1985.

Dozon, J.-P. Frères et sujets: La France et l'Afrique en perspective. Paris: Flammarion, 2003.

Evans, M. and E. Godin. France 1815-2003. London: Arnold, 2004.

Gautier, H., in L'adaptation de l'enseignement aux colonies: Rapports et compte rendu du Congrès intercolonial de l'enseignement dans les colonies et dans les pays d'outre-mer, 25-27 septembre 1931, prepared for the Exposition Coloniale Internationale 1931. Paris: H. Didier, 1931. 
Gbagbo, L. Réflexions sur la conférence de Brazzaville. Yaoundé: Eds Clé, 1978.

Genova, J. Colonial Ambivalence, Cultural Authenticity, and the Limitations of Mimicry in Frenchruled West Africa, 1914-1956. New York: Peter Lang, 2004.

Ginio, R. French Colonialism Unmasked: The Vichy Years in French West Africa. Lincoln, NE: University of Nebraska Press, 2006.

Girardet, R. L'Idée coloniale en France. Paris: Table Ronde, 1972.

Guèye, D. Sur les sentiers du temple: Ma rencontre avec Félix Houphouët-Boigny. Ventabren: Les Rouyat, 1975.

Hunt, L. Politics, Culture and Class in the French Revolution. London: Methuen, 1986.

Jézéquel, J.-H. 'Les enseignants comme élite politique en AOF (1930-1945)'. Cahiers d'études africaines 45, no. 2 (2005): 519-43.

LeVine, V. T. Political Leadership in Africa. Stanford, CA: Stanford University, Hoover Institution on War, Revolution and Peace, 1967.

- Politics in Francophone Africa. Boulder, CO: Lynne Rienner, 2004.

Mangan, J. A., ed. Making Imperial Mentalities. Manchester: Manchester University Press, 1990.

Mumford, W. B. Africans Learn to be French. London: Evans Brothers, n. d. (c. 1935).

'Une pépinière d'hommes politiques: L'Ecole William-Ponty'. Europe-France Outre-Mer July 1960, pp. $22-23$.

Person, Y. 'Le Front populaire au Sénégal'. Mouvement social 107 (1979): 72-102.

Price, R. A Concise History of France. Cambridge: Cambridge University Press, 1993.

Rosanvallon, P. Le Modèle politique français. Paris: Seuil, 2004.

Sabatier, P. 'Educating a Colonial Elite: The William Ponty School and its Graduates'. Unpublished $\mathrm{PhD}$ thesis, University of Chicago, 1977. " Elite" Education in French West Africa: The Era of Limits'. International Journal of African Historical Studies 11, no. 2 (1978): 247-66.

Sarraut, A. Grandeur et servitude coloniales. Paris: Eds du Sagittaire, 1931.

Schachter-Morgenthau, R. Le Multipartisme en Afrique de l'ouest francophone jusqu'aux indépendances. Paris: L'Harmattan, 1998.

Senghor, L. S. Liberté 1: Négritude et humanisme. Paris: Seuil, 1964.

Siriex, P.-H. Félix Houphouët-Boigny: l'homme de la paix. Paris: Seghers, 1975.

Spiegler, J. S. 'Aspects of Nationalist Thought among French-Speaking West Africans, 1921-39'. Unpublished $\mathrm{PhD}$ thesis, Nuffield College, Oxford, 1968.

Suret-Canale, J. Les Groupes d'Etudes Communistes (GEC) en Afrique noire. Paris: L'Harmattan, 1994.

Thomas, M. The French Empire between the Wars: Imperialism, Politics and Society. Manchester: Manchester University Press, 2005.

Vaillant, J. G. French and African: A Life of Léopold Sédar Senghor. Cambridge, MA: Harvard University Press, 1990.

Wesley Johnson, G. 'The Triumph of Nationalism in French West Africa, or the Change from Assimilation to Nationalism as a Secular Faith for West African Elites'. In Décolonisations européennes, edited by M. Michel. Aix-en-Provence: Publications de l'Université de Provence, 1995.

Wilder, G. The French Imperial Nation-State: Négritude and Colonial Humanism between the Two World Wars. Chicago, IL: University of Chicago Press, 2005.

Wright, G. France in Modern Times. 3rd edn. New York: Norton, 1985.

Zan, S.-B. Ouezzin Coulibaly: Le Lion du RDA. Abidjan: Presses Universitaires de Côte d'Ivoire, 1995. 